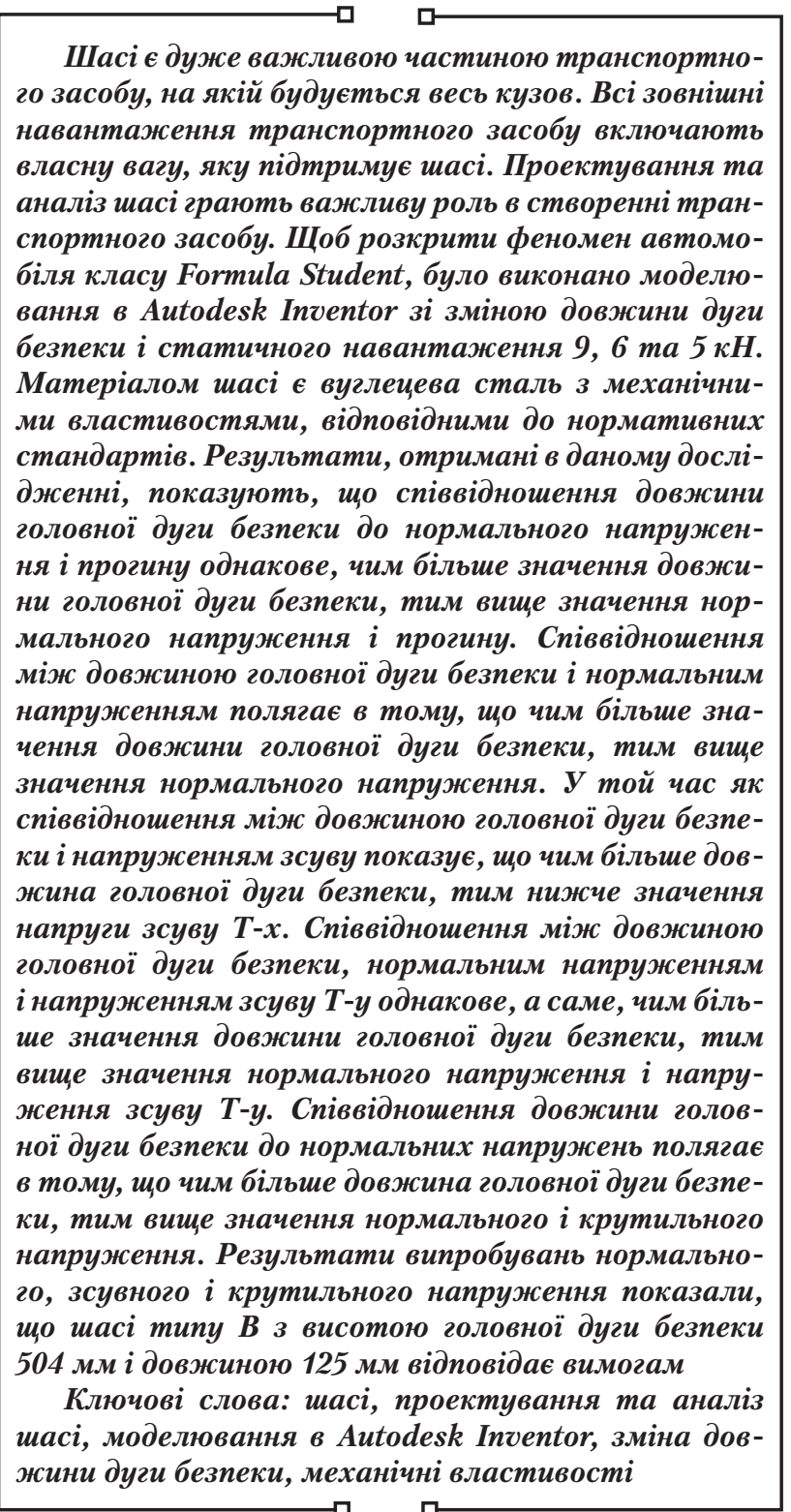

Шасі є дуже важливою частиною транспортного засобу, на якій будується весь кузов. Всі зовнішні власну вагу, яку підтримує шасі. Проектування та аназ шасі грають важслву роль в створенні транвання в Autodesk Inventor зі зміною довжини дуги безпеки і статичного навантаження 9, 6 та 5 кH. Матеріалом шасі є вуглечева сталь з механіннидженні, показують, що співвідночення довжини головної дуги безпеки до нормального напруження $і$ прогину однакове, чим більше значення довжиміж довжиною головноі дуги безпеки і нормальним напруженням полягає в тому, що чим більще значення довжини головноі дуги безпеки, тим вище співвідношення між довжиною головної дуги безпеки і напруженням зсуву показує, що чим більше дові напруженням зсуву T-у однакове, а саме, чим більвище значення нормального напруження $i$ напруження зсуву Т-y. Співвідношення довжини головної дуги безпеки до нормальних напружень полягає ки, тим вище значення нормального і крутильного напруження. Результати випробувань нормально04 мм і довжиною 125 мм відповідає вимогам жини дуги безпеки, механічні властивості

\section{MODELING ANALYSIS OF THE EFFECT OF THE MAIN ROLL- HOOP LENGTH ON THE STRENGTH OF FORMULA STUDENT CHASSIS}

Rudi Siswanto

Masters of Mechanical Engineering, Researcher*

E-mail: rudisiswanto@ulm.ac.id

Rachmat Subagyo

Doctor of Mechanical Engineering, Researcher* E-mail: rachmatsubagyo@ulm.ac.id

Hajar Isworo

Masters of Mechanical Engineering, Researcher*

E-mail: hajarisworo@gmail.com

Femiana Gapsari

Doctor of Mechanical Engineering, Researcher Department of Mechanical Engineering

Brawijaya University

J. Mayjen Haryono, 167, Malang, Indonesia, 65145

E-mail: femianagapsari@gmail.com *Department of Mechanical Engineering

Lambung Mangkurat University J. Brigjen. H. Hasan Basri, Kotak Pos 219, Banjarmasin, Indonesia, 70123

\section{Introduction}

Chassis is an important part of a vehicle because it supports the entire body of the vehicle. The external load of the vehicle, including its own weight, is borne by the chassis. In essence, chassis design and analysis are very important in the process of making vehicles. To design a vehicle chassis that is the most appropriate as desired is the most complicated task. This is caused by very complex design and analysis factors. To overcome this problem, a numerical analysis method is needed.

To design and make frame structures requires special knowledge especially in design, material selection, metal joining and fabrication to produce a sturdy and competitive chassis design. The design results reflect the success of the chassis, especially if used for racing competitions. This study focuses on the analysis of the initial chassis design using Autodesk Inventor 2015 to test deflection and stress.
When chassis accepts static and dynamic loading is a complex problem and needs to be calculated in detail. Many accidents on vehicles are caused by chassis failure. To minimize this, a chassis must be designed as well as possible. The combined analysis method by calculating the relationship of normal stresses to deflection, shear stress and torsional is a method that needs to be done to overcome the failure of the chassis.

\section{Literature review and problem statement}

The paper [1] presents the results of the study that accidents are mostly caused by loss of stability in the frame structure and a substantial reduction in the carrying capacity of the structure on the chassis. This shows that the stability and carrying capacity of the frame are very important for driver 
safety. Careful chassis planning is very important. However, the cost is very large and difficult to do if the results of the planning are tested by making real objects. To overcome this, the researchers used numerical methods to simplify the work. Chassis design with numerical methods includes ANSYS [2], FEM [3], CATIA V5R19 [4], ANSYS / LS-DYNA [5] and finite element models [6].

The design of a chassis that has a lightweight material [7], ergonomics and ease in the manufacturing process [8] is the aim of the researchers. To achieve this, the design of a model that requires natural frequency and characteristics is appropriate so that it can ensure comfort while driving [9]. Apart from having a chassis comfort factor, it must also be able to absorb energy during a collision [10]. The lightweight chassis design affects fuel consumption [11].

Development of the type of chassis material is also very necessary, especially in supporting the strength of the material. The fatigue factor that occurs when the material is used continuously, supports the failure of the chassis. To overcome this, it is very necessary to create a chassis that has superior strength. Unwittingly when making the chassis material, defects often occur in the chassis material. The process of making chassis materials needs to use specialized technology that is qualified. As research conducted by [12], a new forging process was carried out to close defects in axial ingots. This forging process is able to reduce the deformation force by 1.5-3.0 times compared to the manufacture using conventional systems. This new technology has been implemented in the industry resulting in a $15-20 \%$ increase in the productivity of the forging process and a decrease in the amount of heating from 8 to 6 during the forging process.

To obtain a minimum chassis failure rate, a combination of material technology and chassis analysis test is needed. Many analysis tests of the chassis have been carried out, as was done by [13]. In this analysis test: Main roll hoop, Front roll hoop, Static slide, Side impact, Torsional static. The disadvantages of this test are only to do the testing separately on each stress and torque, regardless of the influence between the two.

The research conducted by [14] tried to analyze the connections in the chassis in a combination of moments, shear forces and axial forces. The results of this analysis are able to increase the strength of welded joints when receiving a combination of moments, shear forces and axial forces that often occur in the chassis. This study proves that combination analysis can reduce the failure of the chassis

Chassis is a very important thing in a vehicle, a strength test on a chassis must be done, this is to avoid the failure of the chassis that causes accidents. The chassis test has only been carried out separately on stress and torque. A combination test on the chassis connection has been carried out and the results are very good. To improve the reliability of the chassis, it is very necessary to test simultaneously between normal, shear and torsional stresses, to find the best optimization value that meets the requirements.

\section{The aim and objectives of the study}

The aim of this study is to determine the length of the main roll hoop that is right on the chassis, so that it meets the security requirements. The length of the main roll hoop is varied $(110-150 \mathrm{~mm})$, the analysis is done in combination between normal stresses and deflection, shear stress and torsional.
To achieve this goal, the following are carried out:

- Analyzing the relationship between normal stresses and deflection, shear stress and torsional.

- Looking for the main roll hoop length that meets the highest security requirements.

\section{Material, methods, and models of research}

This research method starts with determining the chassis material using carbon steel, grade: A36 as shown in Table 1. Where the value of mechanical properties is shown in Table 1. Simulation using Autodesk Inventor Student version, resulting in value stress due to loading whose value is below the yield value on carbon steel, to obtain a high level of security.

Table 1

Mechanical properties of carbon steel

\begin{tabular}{|c|c|}
\hline Mechanical Properties & Value \\
\hline Density & $7.850 \mathrm{~g} / \mathrm{cm}^{3}$ \\
\hline Young's Modulus & $200 \mathrm{GPa}$ \\
\hline Poisson's ratio & 0.290 \\
\hline Yield strenght & $350 \mathrm{MPa}$ \\
\hline Ultimate Tensile Strength & $420 \mathrm{MPa}$ \\
\hline Thermal Conductivity & $47.600 \mathrm{~W} / \mathrm{m} \cdot \mathrm{K}$ \\
\hline Linear Expansion & $0.00001201 / \mathrm{K}$ \\
\hline Spesific heat & $0.480 \mathrm{~J} / \mathrm{kg} \cdot \mathrm{K}$ \\
\hline
\end{tabular}

The material dimensions used in this chassis are round tube $26.9 \times 2.5 \mathrm{~mm}$ for front components and roll hope play, while other components such as roll hoop bracing, front bulkhead, side impact structure and main parts of the frame use a round tube $26.9 \times 2 \mathrm{~mm}$. The structure of the hollow chassis aims to lighten the weight of the chassis designed. The chassis frame design is shown in Fig. 1, where the roll hoop height is determined to be $504 \mathrm{~mm}$. While the roll hoop length is varied with values between $110-150 \mathrm{~mm}$. The car chassis that was investigated was the chassis of the Formula Society of Automotive Engineers (FSAE).

This research begins with the making of three-dimensional model design, by making variations in the types of roll hoops: $A, B, C, D, E, F, G, H$ and $I$ as shown in Fig. 1 . Then the length of the roll hoop is made 9 variations with the values of each are: 110, 115, 120, 125, 130, 135, 140, 145 and $150 \mathrm{~mm}$. By using Autodesk Inventor the student version is simulated to test: Deflection, Normal stress, Shear stress, and Torsional stress. The results of this test are used to analyze variations in the length of the roll hoop that has been designed so that the best chassis design is obtained.

The simulation process is carried out with the following stages (Fig. 2): Installing Autodesk Inventor 2015 software on the Note Book, creating a 2015 FSAE chassis with variations in roll hoop length, testing the chassis includes (deflection, stress and torsional), boundary conditions (tension $<$ yield stress, deflection $<25 \mathrm{~mm}$ ), design analysis and completion.

Fig. 3. is a form of skeletal design that is made with static loading F1, F2 and F3 with a load of 9, 6 and $5 \mathrm{kN}$. Where $\mathrm{F} 1$ is loading in the vertical direction of the $y$-axis, F2 in the horizontal direction of the $x$-axis and F3 is the loading of the $z$-axis direction. The reactions that occur due to static loading R1, R2, R3, and R4 are shown in Fig. 3 (circle sign). 

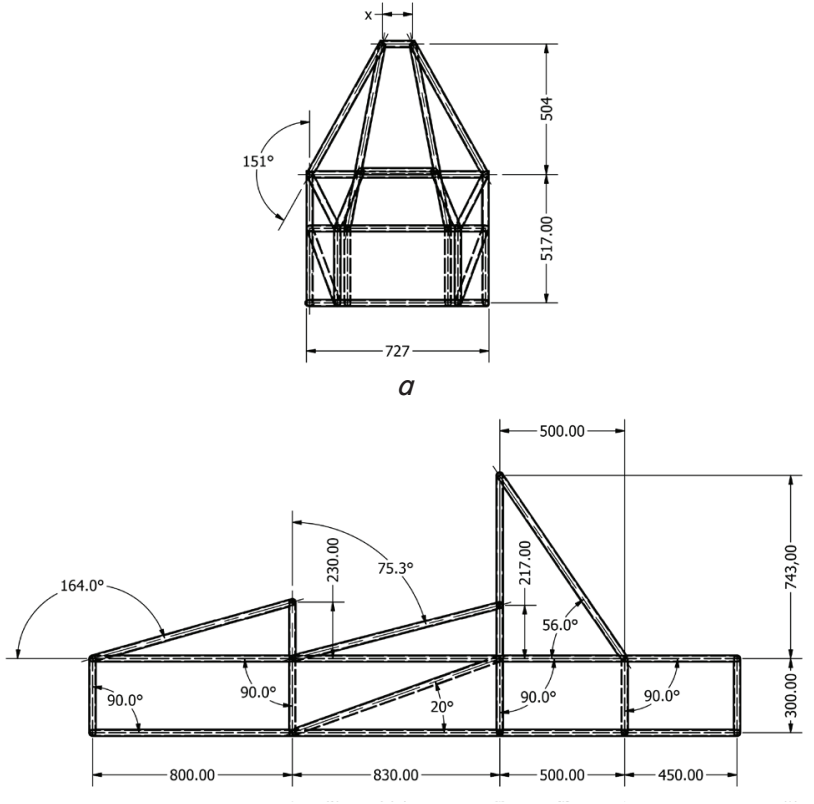

$b$

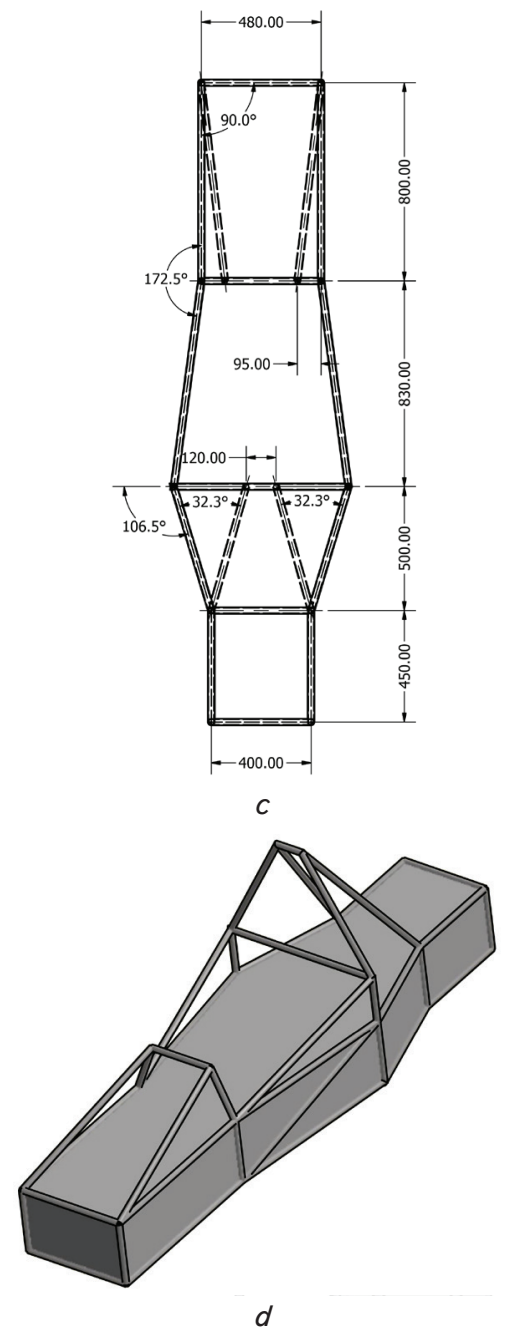

Fig. 1. Planned chassis dimensions:

$a$ - front view; $b$ - right side; $c$ - top view; $d$ - object

The rules for the magnitudes of the loading forces of chassis followed the FSAE 2015.

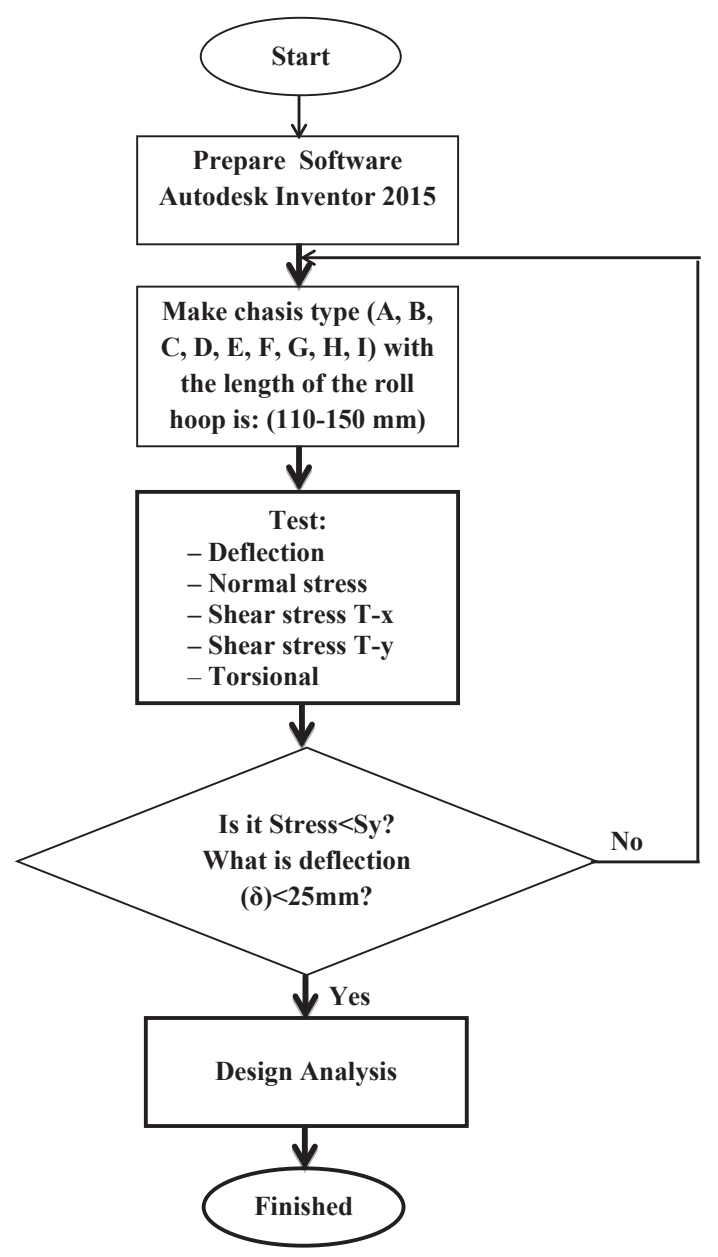

Fig. 2. Flow chart stages of research

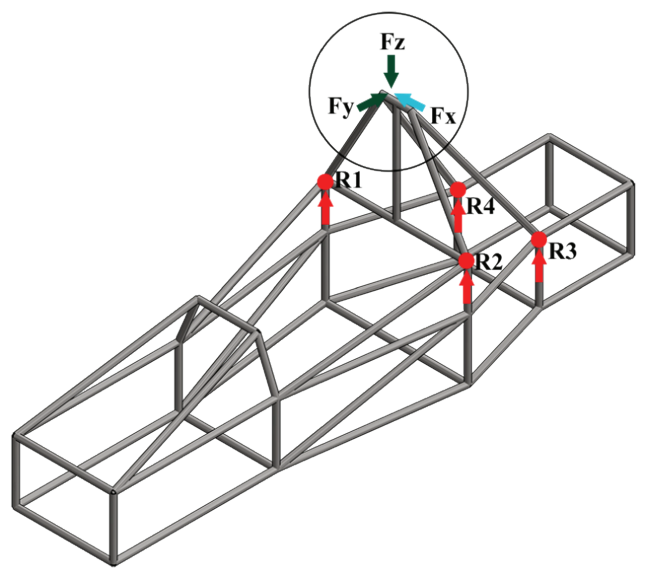

Fig. 3. Load diagram on frame model: $F 1=9 \mathrm{kN}, F 2=6 \mathrm{kN}$ and $\mathrm{F} 3=5 \mathrm{kN}$ with support R1, R2, R3 and R4

5. Research results of analysis of the modeling of the effects of roll hoop length on chassis strength

Test results with Autodesk inventor on deflection, normal stress, shear stress and torsional are shown in Table 2. With variations in the length of the main roll hoop type $(A-I)$ are: $110,115,120,125,130,135,140,145$ and $150 \mathrm{~mm}$.

Fig. 4 shows the Autodesk Inventor simulation results on the $110 \mathrm{~mm}$ roll hope. 
Table 2

Autodesk Inventor simulation results on Deflection test, Normal stress, Shear stress $T-x$, Shear stress $T-y$ and torsional on roll hoop height: $504 \mathrm{~mm}$ with variations in the main roll hoop type $(A-I)$ length

\begin{tabular}{|c|c|c|c|c|c|c|}
\hline $\begin{array}{c}\text { Chasis } \\
\text { type }\end{array}$ & $\begin{array}{c}\text { Main roll hoop length } \\
(\mathrm{mm})\end{array}$ & $\begin{array}{c}\text { Deflection } \\
(\mathrm{mm})\end{array}$ & $\begin{array}{c}\text { Normal stress } \\
(\mathrm{MPa})\end{array}$ & $\begin{array}{c}\text { Shear stress } T-x \\
(\mathrm{MPa})\end{array}$ & $\begin{array}{c}\text { Shear stress } T-y \\
(\mathrm{MPa})\end{array}$ & $\begin{array}{c}\text { Torsional } \\
(\mathrm{MPa})\end{array}$ \\
\hline A & 110 & 1.002 & 290.4 & 65.46 & 22.75 & 12.61 \\
\hline B & 115 & 1.097 & 292.1 & 65.22 & 30.11 & 13.20 \\
\hline C & 120 & 1.138 & 312.6 & 64.99 & 22.49 & 13.77 \\
\hline D & 125 & 1.197 & 255.9 & 66.81 & 3.13 & 14.33 \\
\hline E & 130 & 1.258 & 323.4 & 64.57 & 30.42 & 14.86 \\
\hline F & 135 & 1.320 & 333.6 & 64.37 & 30.50 & 15.38 \\
\hline G & 140 & 1.383 & 343.8 & 64.18 & 30.57 & 15.88 \\
\hline H & 145 & 1.448 & 337.2 & 67.62 & 3.40 & 16.37 \\
\hline I & 150 & 1.514 & 369.3 & 28.95 & 65.75 & 16.84 \\
\hline
\end{tabular}

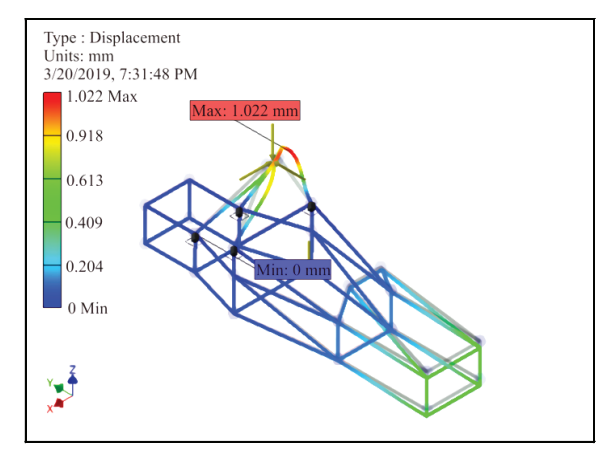

a

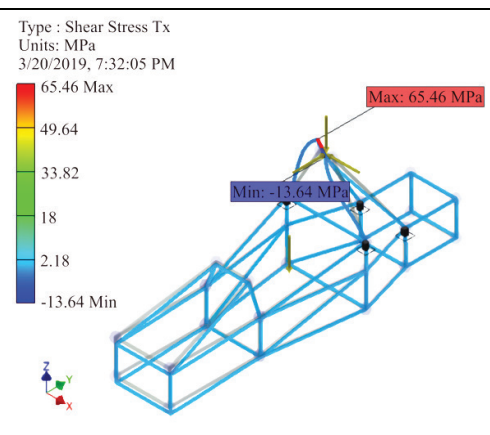

C

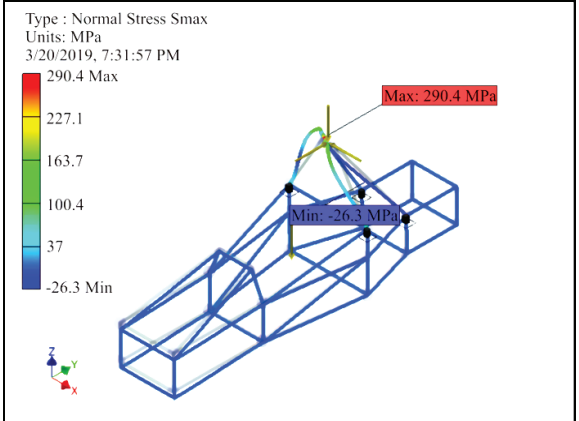

$b$

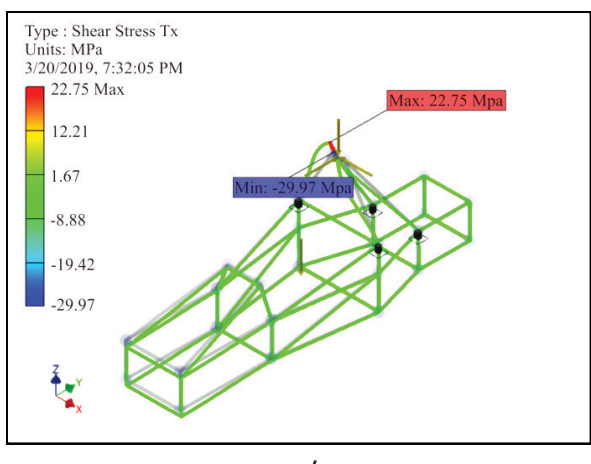

d

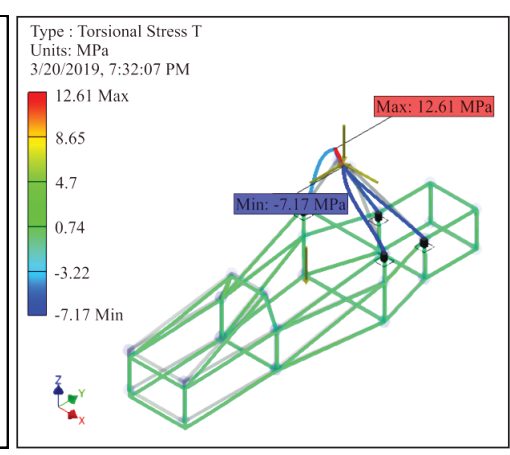

e

Fig. 4. Autodesk Inventor simulation results on the length of the $110 \mathrm{~mm}$ roll hoop: $a$ - Deflection test; $b$ - Normal Stress Test; $c-T-x$ shear stress test; $d-$ Shear stress test $T-y$; $e-$ Torsional stress test

Tests carried out include: Deflection Test, Normal Stress Test, $T-x / T-y$ shear stress test and torsional test. The results of this test produce a deflection value $=1.022 \mathrm{~mm}$; normal stress value $=290.4 \mathrm{MPa}$; shear stress value $T-x=$ $=65.46 \mathrm{MPa}$, shear stress value $T-y=22.75 \mathrm{MPa}$ and torsional value $=12.61 \mathrm{MPa}$.

The visualization result of the deflection test with Autodesk inventor is shown in Fig. 4, $a$, the normal stress test is shown in Fig. 4, $b$, the shear stress test $T-x$ and $T-y$ are shown in Fig. 4, $c, d$, and torsional test shown in Fig. 4, $e$.

Plastic deformation is not taken into account in this study, because it is not safe. In this planning, the stress that occurs under the allowable stress is given.

\section{Discussion of the research results of analysis of the modeling of the effects of roll hoop length on chassis strength}

Fig. 5 shows the relationship between the roll hoop length and normal and shear stresses. In this graph, there are three best long roll hoop designs, namely: type $C$ (red ellipse), $D$ (black ellipse) and $E$ (green ellipse). The normal displacement and stress values for each type $C, D$ and $E$ are: $(1.138 \mathrm{~mm}, 312.6 \mathrm{MPa}),(1.197 \mathrm{~mm}, 255.9 \mathrm{MPa})$ and $(1.258 \mathrm{~mm}, 323.4 \mathrm{MPa})$. The results of the comparison between the three types of chassis indicate that the deflection value in $C$-type chassis is lower when compared to chassis 
types $D$ and $E$. But the value of normal stress on type $D$ chassis is the lowest compared to the values of normal stresses on chassis types $C$ and $E$, consideration of the limit of Yield strength values in Table 1 , then type $D$ chassis meet more requirements than others. The relationship between the roll hoop length and normal stress and deflection is the same, the greater the value of roll hoop length, the greater the normal value of stress and deflection.

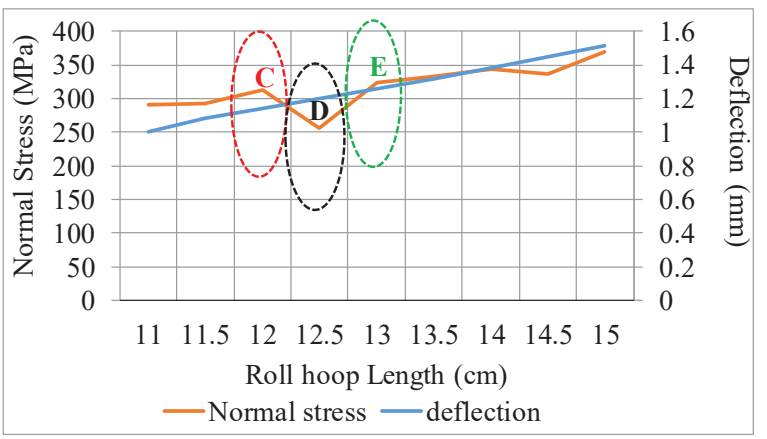

Fig. 5. Relationship between the roll hoop length and normal stress and deflection

Fig. 6 is a simulation result with Autodesk Inventor on normal stress and deflection of chassis types $C, D$ and $E$. The normal value of stress that occurs shows almost the same results as shown in Fig. 5, $c-e$ where the highest normal stress value occurs at the top of the chassis with light green. The highest displacement value occurs at the top of the chassis with red on the chassis types $C, D$, and $\mathrm{E}$ as shown in Fig. $6, b, d, f$.

The results of the graph of the relationship between the roll hoop length and normal stress and shear stress $T-x$ are shown in Fig. 7.
The results of analysis on chassis types $D, E$ and $G$ have the following values: (255.9 MPa, 66.81 MPa), (323.4 MPa, 64.57 MPa) and (337.2 MPa, 67.62 MPa). The lowest normal stress value occurs in type $D$ chassis with a value of 255.9 MPa and $T-x$ shear stress in type $E$ chassis with a value of $64.57 \mathrm{MPa}$. To determine the best value is to find the smallest stress difference between normal stress and shear stress as shown in Table 3.

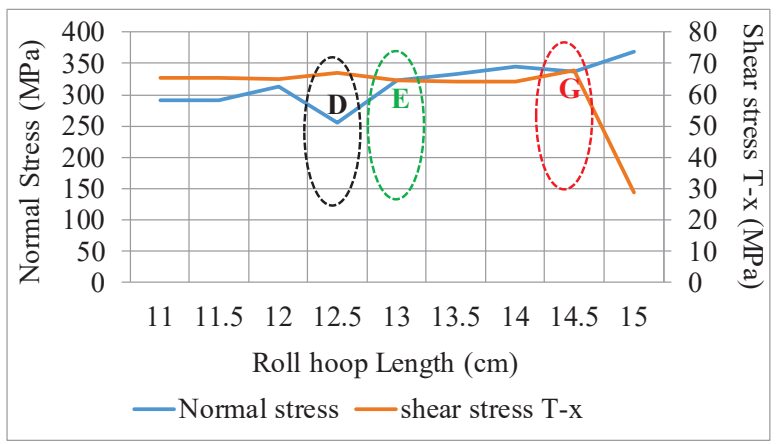

Fig. 7. Relationship between the roll hoop length and normal stress and shear stress $T-x$

Table 3

Comparison of the difference between the normal values of stress on Shear stress $T-x$ with the variation of the main roll hoop length

\begin{tabular}{|c|c|c|c|c|c|}
\hline $\begin{array}{c}\text { Chas- } \\
\text { sis } \\
\text { type }\end{array}$ & $\begin{array}{c}\text { Main } \\
\text { roll hoop } \\
\text { length } \\
(\mathrm{mm})\end{array}$ & $\begin{array}{c}\text { Normal } \\
\text { stress } \\
(\mathrm{MPa})\end{array}$ & $\begin{array}{c}\text { Shear } \\
\text { stress } T-x \\
(\mathrm{MPa})\end{array}$ & $\begin{array}{c}\text { Stress } \\
\text { difference } \\
(\mathrm{MPa})\end{array}$ & Decision \\
\hline$D$ & 125 & 225.9 & 66.81 & 189.09 & The best value \\
\hline$E$ & 130 & 323.4 & 64.57 & 258.83 & - \\
\hline$G$ & 145 & 337.2 & 67.62 & 269.58 & - \\
\hline
\end{tabular}
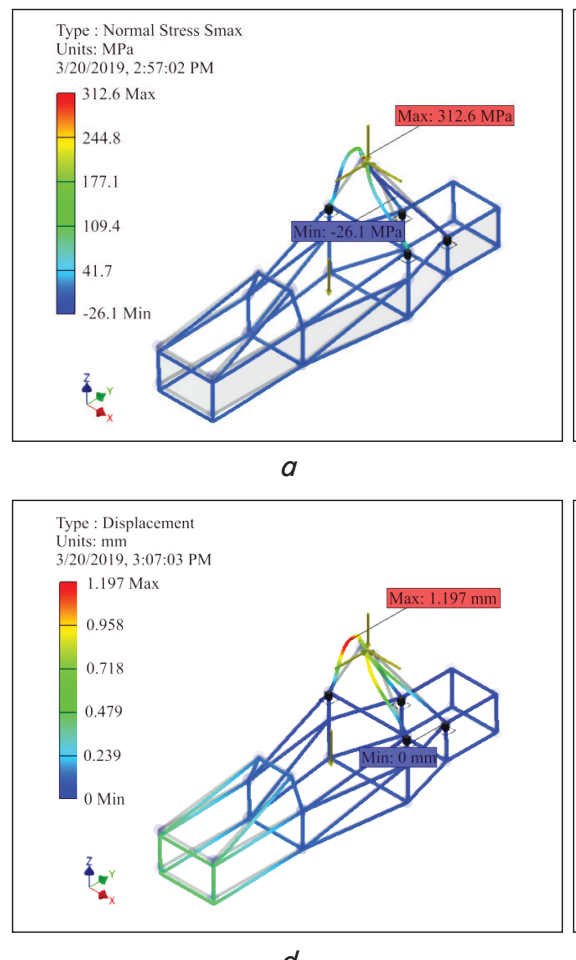

$d$
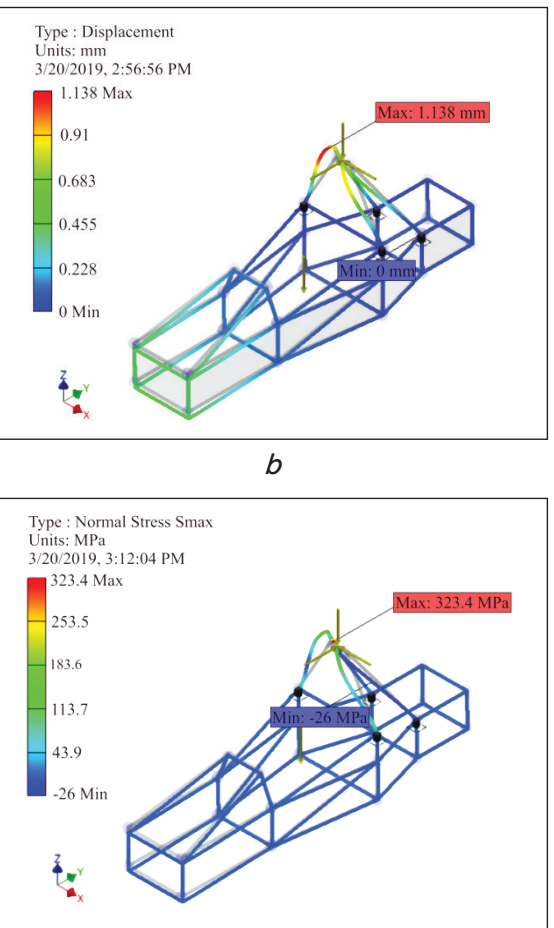

e
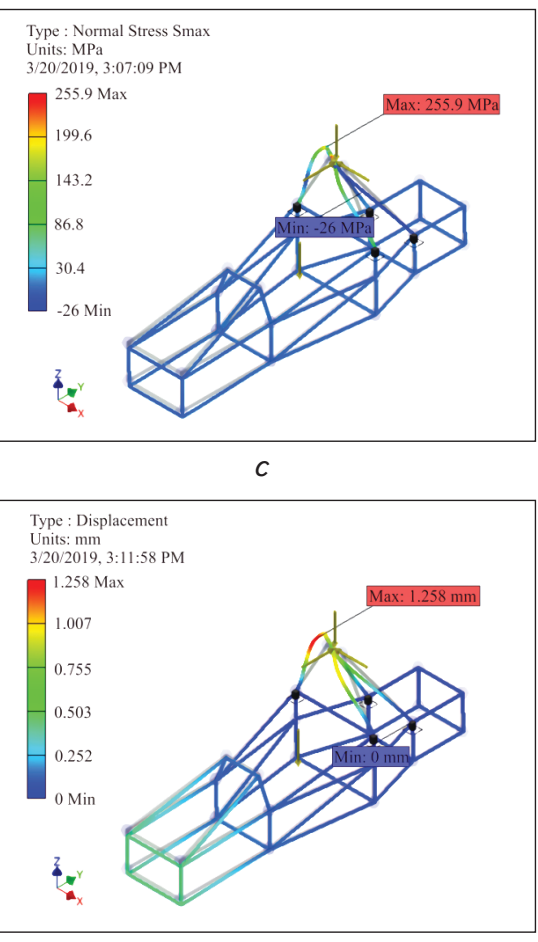

$f$

Fig. 6. Autodesk Inventor simulation results on: $a-$ normal stress and $b$ - deflection in chassis type: $C$; $c-$ normal stress and $d$-deflection in chassis type: $D ; e$ - normal stress and $f$-deflection in chassis type: $E$ 
The smallest stress difference in the material increases the safety factor in the chassis. The results of this stress difference show that type $\mathrm{D}$ chassis has the lowest value: 189.09 MPa. The relationship between the roll hoop length and normal stress, the greater the value of the roll hoop length, the greater the normal stress value. While the relationship between the roll hoop length and shear stress is the greater the value of the roll hoop length, the lower the $T-x$ shear stress value.

The simulation results with Autodesk Inventor on chassis types $D, E$, and $G$ are shown in Fig. 8. It appears that the normal visualization of stress shows the same results as shown in Fig. 8, $a, c, e$. The highest normal stress occurs at the top of the roll hoop shown in green. Different things happen in shear stress $T$-x , the lowest stress value occurs in type $E$ chassis (Fig. 8, $d$ ), followed by type $E$ and type $G$ chassis. Shear stress in type $D$ and $G$ chassis is dominated by green and slightly red while the type $E$ chassis is dominated by light blue and slightly red. The shear stress value of type $E$ chassis is the lowest when compared to types $D$ and $G$. But the analysis of the difference between normal stress and shear stress in Table 3 shows that the type $D$ chassis stress difference is the best.

Fig. 9 shows the relationship between the roll hoop length and normal stress and $T-y$ shear stress. From this graph there are two types of chassis that are the best, namely: chassis type $D$ and type $G$. Each of these chassis has the normal values of stress and shear stress as follows: (255.9 MPa, $3.13 \mathrm{MPa}$ ) and (337.2 $\mathrm{MPa}, 3.40 \mathrm{MPa})$. The analysis shows that type $D$ chassis has the normal value of stress and the best shear stress. This is supported by the difference between normal stress and lower shear stress as shown in Table 4.

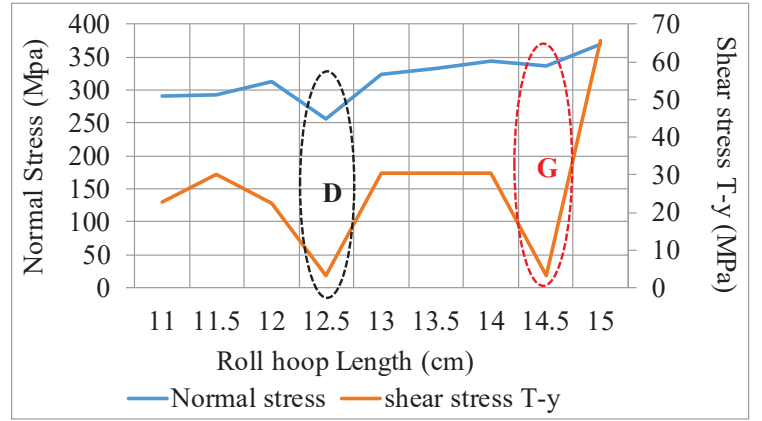

Fig. 9. Relationship between the roll hoop length and normal stress and shear stress $T-y$

Table 4

Comparison of the difference between the value of Normal Stress and $T-y$ shear stress with the variation of the length of the main roll hoop

\begin{tabular}{|c|c|c|c|c|c|}
\hline $\begin{array}{c}\text { Chas- } \\
\text { sis } \\
\text { type }\end{array}$ & $\begin{array}{c}\text { Main } \\
\text { roll hoop } \\
\text { length } \\
\text { (mm) }\end{array}$ & $\begin{array}{c}\text { Nor- } \\
\text { mal } \\
\text { stress } \\
(\mathrm{MPa})\end{array}$ & $\begin{array}{c}\text { Shear } \\
\text { stress } \\
T-y \\
(\mathrm{MPa})\end{array}$ & $\begin{array}{c}\text { Stress } \\
\text { difference } \\
(\mathrm{MPa})\end{array}$ & Decision \\
\hline$D$ & 125 & 255.9 & 3.13 & 252.77 & The best value \\
\hline$G$ & 145 & 337.2 & 3.40 & 333.80 & - \\
\hline
\end{tabular}

Based on these considerations, choosing type $D$ chassis is the best. The relationship between the roll hoop length and normal stress and shear stress $T-y$ is the same, the greater the value of the roll hoop length, the higher the value of normal stress and shear stress $T-y$.

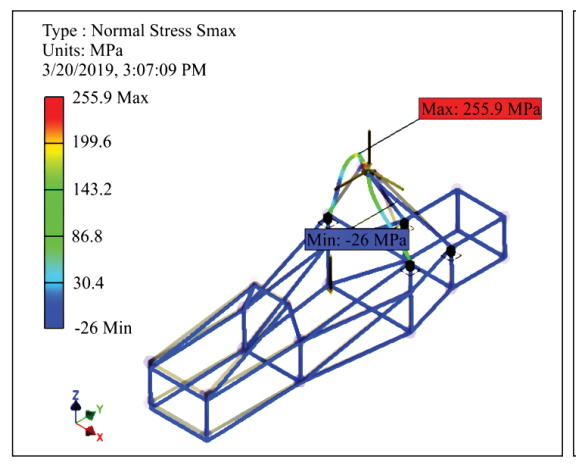

$a$

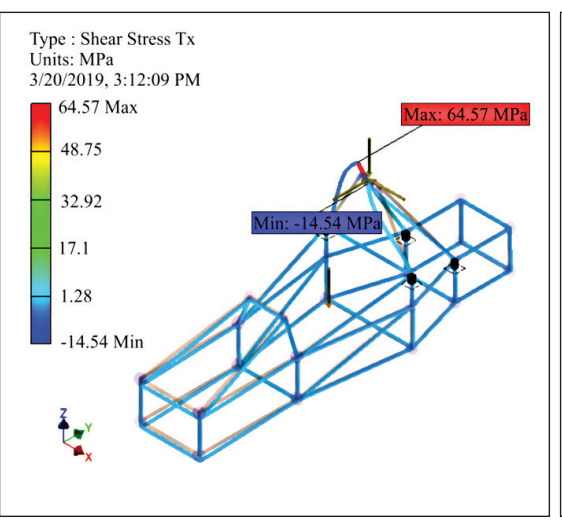

d

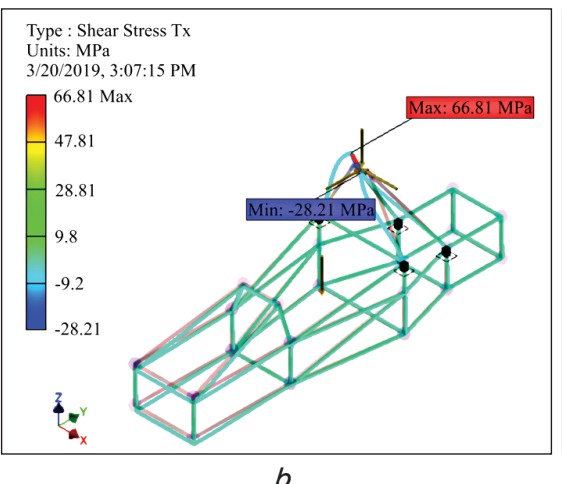

$b$

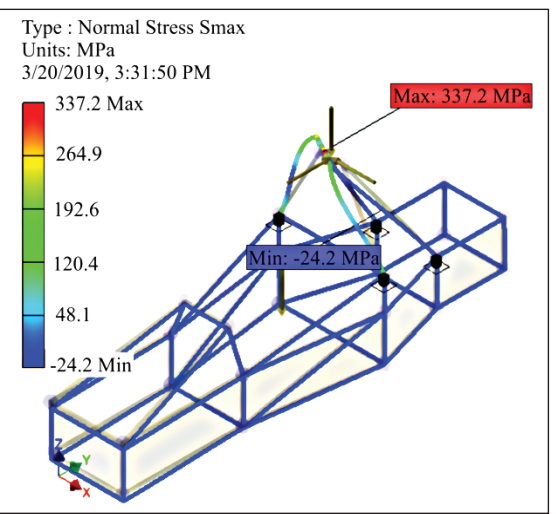

e
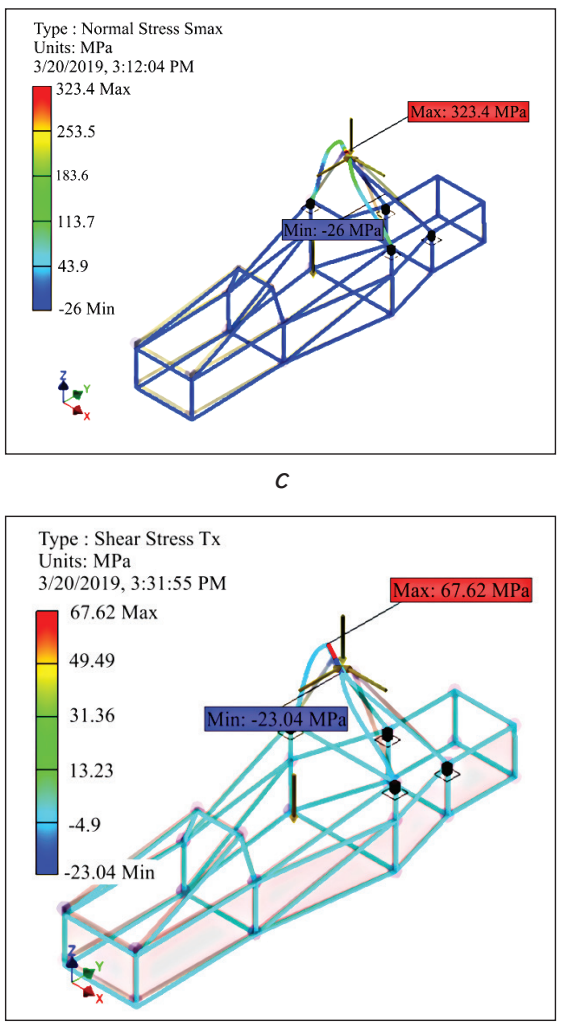

$f$

Fig. 8. Autodesk Inventor simulation results on: $a-$ Normal stress test;

$b$ - Shear stress $T-x$ in type $D$ chassis; $c$ - Normal stress test; $d$-Shear stress $T-x$ in type $E$ chassis;

$e-$ Normal stress test; $f-$ Shear stress $T-x$ on type $G$ chassis 
The visualization results of each chassis are shown in Fig. 10. Normal stress visualization shows results that are not much different from the two. At the peak of the chassis, the highest stress is represented by green as shown in Fig. 10, $a, c$. The results of the visualization of the Shear stress $T-y$ test show differences in the results of chassis type $D$ and type $G$ where: the peak of type $D$ chassis is dominated by red and light blue (Fig. 10, $b$ ) which shows a lower value compared to the shear stress on the chassis type $G$ indicated by (Fig. 10, $d$ ).

The important thing is that there is a difference in the stress gradient that occurs at the top of the chassis as shown in Fig. 10, $b, d$. The analysis results showed a higher stress difference in the $G$ type chassis compared to the $D$ type chassis. High stress difference affects the safety factor in the chassis. From the results of this analysis, the type $D$ chassis has better security than the type $G$ chassis. The small stress difference has an effect on the safety of the chassis, this is due to the high stress gradient which affects the residual stress which will cause cracks in the chassis frame.

Fig. 11 shows a graph of the relationship between the roll hoop length and the value of normal stress and torsional stress, the simulation results show there are three types of chassis, namely: chassis type $C$ (red ellipse), $D$ (black ellipse) and $E$ (green ellipse). Each chassis has the following normal stress and torsional stress values: (312.6 $\mathrm{MPa}, 13.77 \mathrm{MPa})$, (255.9 MPa, 14.33 MPa) and (323.4 MPa, 14.86 MPa).

The lowest results of normal stress values were obtained in type $D$ chassis, but for torsional stress values obtained in type $C$ chassis with a torsional stress value: $13.77 \mathrm{MPa}$. To determine the best value in both chassis, it is done by calculating the stress difference between normal stress and torsional stress. The results of this calculation are shown in Table 5 .

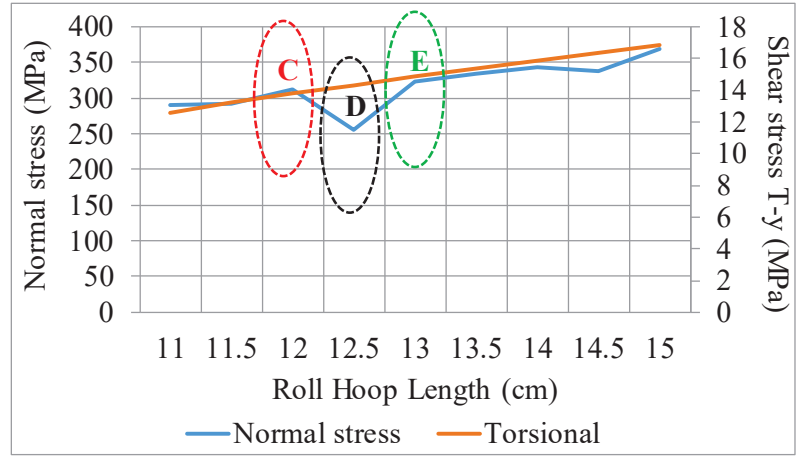

Fig. 11. Graph of the relationship between the main roll hoop length and torsional stress

Table 5

Comparison of the difference between the value of Normal Stress and Torsional with the variation of the main roll hoop length

\begin{tabular}{|c|c|c|c|c|c|}
\hline $\begin{array}{c}\text { Chas- } \\
\text { sis } \\
\text { type }\end{array}$ & $\begin{array}{c}\text { Main } \\
\text { roll hoop } \\
\text { length } \\
(\mathrm{mm})\end{array}$ & $\begin{array}{c}\text { Normal } \\
\text { stress } \\
(\mathrm{MPa})\end{array}$ & $\begin{array}{c}\text { Torsional } \\
\text { stress } \\
\text { (MPa) }\end{array}$ & $\begin{array}{c}\text { Stress } \\
\text { difference } \\
\text { (MPa) }\end{array}$ & Decision \\
\hline$C$ & 120 & 312.6 & 13.77 & 298.83 & - \\
\hline$D$ & 125 & 255.9 & 14.33 & 241.57 & The best value \\
\hline$E$ & 130 & 323.4 & 14.86 & 308.54 & - \\
\hline
\end{tabular}

With the best value obtained in type $D$ chassis. The relationship between the roll hoop length and normal stress and torsional is the greater the value of the roll hoop length, the higher the normal stress and torsional value. To analyze in more detail, visualization of torsional simulations on chassis types $C, D$, and $E$ is displayed. Of the three images, the focus is on the top of the chassis. The torsional analysis results show the similarity between the three chassis. This is caused by the value of the torsional stress which is not too far away.

The advantages of this study are the variables studied more so they can find out the lower limit and the maximum limit of the roll hoop length. Combining analysis between normal stress and deflection, shear stress $(T-x / T-y)$ and torsional. Comparative research refers to reference [13].

This analysis uses only simulations, not yet accompanied by experimental testing. Need further research to implement it.

The development of this research should be continued on experimental testing to find out the weaknesses of the results of this analysis. Threat: The possibility of failure of the results of this analysis is due to differences in the simulation and experimental results. To minimize it needs to be verified further. 


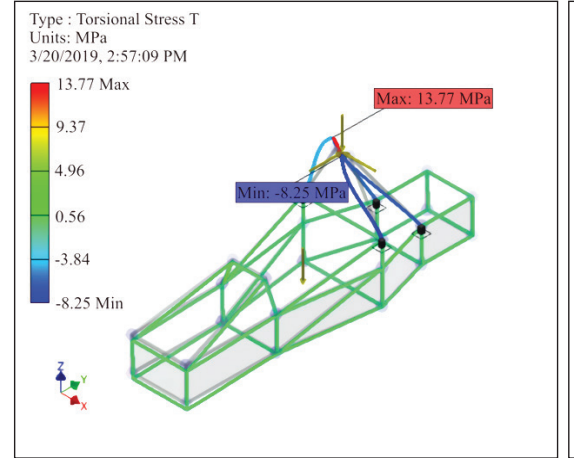

$a$

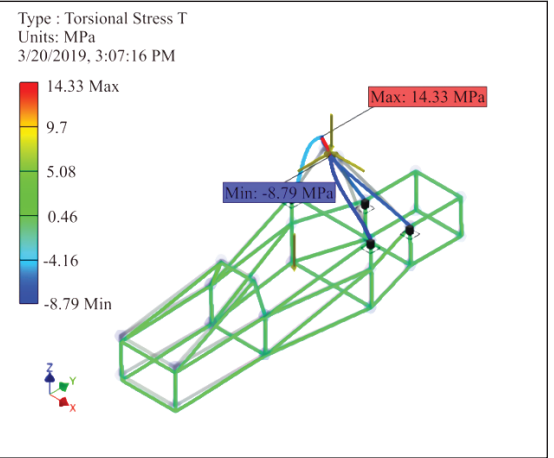

$b$

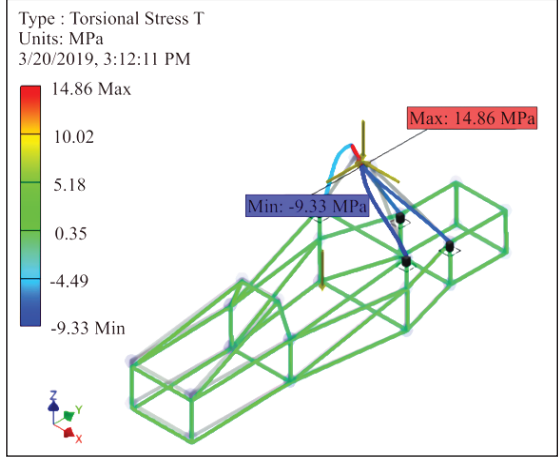

$c$

Fig. 12. Autodesk Inventor torsional simulation results on the main roll hoop length: $a-120 \mathrm{~mm} ; b-125 \mathrm{~mm} ; c-130 \mathrm{~mm}$

\section{Conclusions}

1. The relationship between the main roll hoop length and normal stress and deflection is that the higher the roll hoop length, the greater the value. The relationship between the main roll hoop length and normal stress and shear stress $(T-x)$ is the opposite, while the shear stress
$(T-y)$ is the same. The relationship between the main roll hoop length and normal stress and torque is the higher the main roll hoop length, the greater the normal stress value and torque.

2. Type $B$ chassis with a $504 \mathrm{~mm}$ high roll hoop and $125 \mathrm{~mm}$ long roll hoop meet the requirements of normal, shear and torsional stress test results.

\section{Reference}

1. Zolina, T. V., Sadchikov, P. N. (2012). Modeling of Structural Behaviour of An Industrial Building with Account for the Variation of Rigidity in the Course of its Operation. Designing and detailing of building systems. Mechanics in civil engineering, 10, 69-76.

2. Marzuki, M. A. B., Abu Bakar, M. A., Mohammed Azmi, M. F. (2015). Designing space frame race car chassis structure using natural frequencies data from ansys mode shape analysis. International Journal of Information Systems and Engineering, 3 (1), 54-63. doi: https://doi.org/10.24924/ijise/2015.11/v3.iss1/54.63

3. Nugroho, U., Anis, S., Kusumawardani, R., Khoiron, A. M., Maulana, S. S., Irvandi, M., Mashdiq, Z. P. (2018). Frame Analysis of UNNES Electric Bus Chassis Construction Using Finite Element Method. Engineering International Conference (EIC2017) AIP Conf. Proc., 1941, 020017-1-020017-4. doi: https://doi.org/10.1063/1.5028075

4. Taufik, A. Z., Rashid, N., lan, M., Faruq, M., Zahir, M. (2014). Electric car chassis design and analysis by using CATIA V5 R19. IOSR Journal of Mechanical and Civil Engineering, 11 (4), 56-69. doi: https://doi.org/10.9790/1684-11435669

5. Wang, H., Tan, K. H., Yang, B., Peng, J. (2017). 15.04: Parametric study on steel beams with fin-plate joints under falling floor impact. Ce/papers, 1 (2-3), 3910-3919. doi: https://doi.org/10.1002/cepa.447

6. Belingardi, G., Obradovic, J. (2010). Design of the Impact Attenuator for a Formula Student Racing Car: Numerical Simulation of the Impact Crash Test. Journal of the Serbian Society for Computational Mechanics, 4 (1), 52-65.

7. Jang, C., Quagliato, L., Murugesan, M., Kim, D., Lee, C., Kim, N. (2017). Material property of metal skin - sheet molding compound laminate structures for the production of lightweight vehicles body frame. Procedia Engineering, 207, 878-883. doi: https:// doi.org/10.1016/j.proeng.2017.10.845

8. Shukla, S., Agnihotri, S., Sahoo, R. R. (2016). Design and Analysis of Formula SAE Chassis. Journal of Aeronautical and Automotive Engineering (JAAE), 3 (1), 26-32.

9. Ramesh kumar, S., Dhandapani, N. V., Parthiban, S., Kamalraj, D., Meganathan, S., Muthuraja, S. (2018). Design and Analysis of Automotive Chassis Frame using Finite Element Method. International Journal of Pure and Applied Mathematics, 118 (20), 961-972.

10. Pamungkas, P. M., Adhitya, M., Sumarsono, D. A. (2017). Design and Analysis of Tubular Space-Frame Chassis with Impact Absorbers on Sports Car Electric Vehicle. International Journal of Innovative Research in Science, Engineering and Technology, 6 (10), 20923-20928.

11. Mat, M. H., Ghani, A. R. A. (2012). Design and Analysis of «Eco» Car Chassis. Procedia Engineering, 41, 1756-1760. doi: https:// doi.org/10.1016/j.proeng.2012.07.379

12. Markov, O. E., Perig, A. V., Zlygoriev, V. N., Markova, M. A., Grin, A. G. (2016). A new process for forging shafts with convex dies. Research into the stressed state. The International Journal of Advanced Manufacturing Technology, 90 (1-4), 801-818. doi: https:// doi.org/10.1007/s00170-016-9378-6

13. Mohamad, M. L., Rahman, M. T. A., Khan, S. F., Basha, M. H., Adom, A. H., Hashim, M. S. M. (2017). Design and static structural analysis of a race car chassis for Formula Society of Automotive Engineers (FSAE) event. Journal of Physics: Conference Series, 908, 012042. doi: https://doi.org/10.1088/1742-6596/908/1/012042

14. Sachin, P., Vyavahare, A. Y. (2014). Effect of Gap on Strength of Fillet Weld Loaded in Out-of-Plane Bending. Advances in Structural Engineering, 2409-2416. doi: https://doi.org/10.1007/978-81-322-2187-6_183 